\section{Chemical and Physical Properties of Soil Amended with Pecan Wood Chips}

\author{
Mohammed B. Tahboub \\ Department of Soil and Crop Sciences, MS-2474, Texas A\&M University, \\ College Station, TX 77843 \\ William C. Lindemann ${ }^{1}$ \\ Department of Plant and Environmental Sciences, MSC 3Q, New Mexico \\ State University, Las Cruces, NM 88003
}

\section{Leigh Murray \\ Department of Statistics, Kansas State University, Manhattan, KS 66506}

Additional index words. Carya illinoinensis, pruning wood, soil physical and chemical properties, organic matter, Aggregate stability, soil moisture content

\begin{abstract}
The pruning wood of pecan [Carya illinoinensis (Wangenh.) K. Koch] is often burned. Chipping and soil incorporation of pruning wood is becoming more popular as a result of environmental constraints on burning. The objective of our research was to determine how pecan wood incorporation into soil affects the soil chemical and physical properties. Pecan wood chips were incorporated into a silty clay soil at rates of 0,4484 , $8968,13,452$, and $17,936 \mathrm{~kg} \cdot \mathrm{ha}^{-1}$ in Summer 2002, 2003, and 2004. Some plots received nitrogen at a rate of $0,15.2,30.5,45.7$, and $61.0 \mathrm{~kg} \cdot \mathrm{ha}^{-1}$ to adjust the $\mathrm{C}: \mathrm{N}$ ratio of trimmings to $30: 1$. Ammonium sulfate, as a nitrogen source to balance the $C: N$ ratio of pecan wood chips, reduced soil $\mathrm{pH}$. However, the wood chip amendments alone did not reduce soil $\mathrm{pH}$. Soil salinity (as determined by electrical conductivity) and bulk density were unaffected by wood chip incorporation regardless of application rate or number of applications. Incorporation of pecan chips had little effect on soil moisture content, but the soil had an inherently high waterholding capacity. Pecan wood chip incorporation significantly increased soil organic matter content and aggregate stability, particularly at the higher application rates and with repeated amendment. The incorporation of pecan pruning wood into the soil appears to improve soil tilth and aggregation while providing growers with an environmentally acceptable means of disposal.
\end{abstract}

Regular additions of organic materials such as animal manures and crop residues are important in maintaining the tilth, fertility, and productivity of soils, protecting them from wind and water erosion and preventing nutrient losses through runoff and leaching. Organic amendments improve soil physical properties by increasing waterholding capacity, soil aggregation, soil aeration, and permeability and decreasing soil crusting and bulk density (Oades, 1984; Tisdall and Oades, 1982). Soil chemical properties are improved by organic amendments through their contribution to soil cation exchange capacity, enhancing the ability of soils to buffer $\mathrm{pH}$ changes, and cation complexation (Magdoff, 1992; Wallace et al., 1990). Soil organic matter enhances soil biological properties. Studies have shown that organic farming leads to higher soil quality and more soil

\footnotetext{
Received for publication 18 Dec. 2007. Accepted for publication 7 Feb. 2008.

This research is a contribution of the New Mexico Agricultural Experiment Station, New Mexico State University.

We thank the New Mexico Pecan Growers Association for their support.

${ }^{1}$ To whom reprint requests should be addressed; e-mailwlindema@nmsu.edu
}

biological activity than conventional farming by increasing soil organic matter content, microbial biomass, diversity, respiration, and dehydrogenase enzyme activity (Boggs et al., 2000; Drinkwater et al., 1995; Reganold, 1993).

In Doña Ana County, NM, alone, an estimated 25,500 $\mathrm{t}$ of pecan pruning wood is produced annually (Cabral, 2005). Much of the pruning wood is burned as an economic means of disposal. However, pruned wood is increasingly chipped and incorporated into the soil as an environmentally viable method of handling the waste. Although more expensive than burning, chipping and soil incorporation avoid burning controls recently imposed by the New Mexico Environment Department and the U.S. Environmental Protection Agency. Burning regulations will probably become more restrictive in the future (New Mexico Air Quality Bureau, 2003).

Chipping and incorporation of pruning wood as an alternative to burning has gained acceptance in areas of the San Joaquin Valley, CA (Holtz, 1999) where environmental regulations have forced growers to adopt alternative ways to deal with the waste. The addition of almond wood chips lowered soil $\mathrm{pH}$, increased soil carbon, and organic matter contents and enhanced water infiltration in soil planted with almond trees in the San
Joaquin Valley, CA (Holtz et al., 2004). However, the application rate was unrealistically high $\left(\approx 410,000 \mathrm{~kg} \cdot \mathrm{ha}^{-1}\right.$ or one-third of soil weight) and resulted in initial immobilization of soil inorganic nitrogen. In a previous report (Tahboub et al., 2007), we found no significant effect of wood chip incorporation on plant-available nitrogen, phosphorus, or potassium at application rates up to 17,936 $\mathrm{kg} \cdot \mathrm{ha}^{-1}$ and concluded that wood chip incorporation was a viable means of wood disposal.

Wood chip incorporation should increase the organic matter content of soils and improve soil chemical and physical properties. The continuous use of hardwood chips for a period of 15 years at an application rate of $7000 \mathrm{~kg} \cdot \mathrm{ha}^{-1} \cdot \mathrm{yr}^{-1}$ in the northeast United States increased organic matter content, aggregate stability, and moisture retention and reduced soil bulk density, $\mathrm{pH}$, and soil erosion (Free, 1971). Sanborn et al. (2004), while studying the effect of wood chip incorporation on the rehabilitation of older landings and roads constructed on fine-textured soils in British Columbia, Canada, found that soil bulk density at 7 to $14 \mathrm{~cm}$ was lowest in the wood chip-amended soil when compared with the topsoil amendments. The wood chip treatment had also the highest 3-year growth rates of hybrid white spruce. Based on these promising results, the authors recommended silviculturists to use chipped wood wastes in the rehabilitation of disturbed lands.

Although our previous report showed that nutrient immobilization was not a concern with pecan wood chip incorporation, the potential beneficial aspects of wood chip incorporation on soil organic matter and the effects on soil chemical and physical properties were not included.

The influence of pecan wood chip incorporation must be viewed over several years and with repeated applications for a clear picture of the beneficial and detrimental effects of this disposal method. Therefore, the objective of this study is to determine how pecan wood incorporation into the soil would affect soil organic matter content, chemical and physical properties, and whether this practice might present an alternative to burning.

\section{Materials and Methods}

As previously described (Tahboub et al., 2007), a field experiment was established at the Leyendecker Plant Science Research Center, New Mexico State University, Las Cruces, NM, in May 2002. The experimental site (lat. $32^{\circ} 12.309^{\prime} \mathrm{N}$, long. $106^{\circ} 45.058^{\prime} \mathrm{W}$ ) is located $14.5 \mathrm{~km}$ south of Las Cruces at an elevation of $1172 \mathrm{~m}$. The mean annual precipitation is $20.3 \mathrm{~cm}$. The soil was a welldrained Glendale clay loam [fine-silty, mixed (calcareous), thermic Typic Torrifluvent] that formed in alluvium. The surface soil ( 0 to 30 $\mathrm{cm}$ ) had an average $\mathrm{pH}$ of 8.7 (saturated paste extract) and electrical conductivity (EC) of $2.24 \mathrm{dS} \cdot \mathrm{m}$.

Pruning wood was ground in a tub grinder and the resulting chips were generally long 
Table 1. Sampling dates of soil characteristics for each number of pecan wood chip applications.

\begin{tabular}{llll}
\hline & & & Sampling date \\
\cline { 2 - 4 } Number of applications & pH and EC & Organic matter & \multicolumn{1}{c}{$\theta v$ and Db } \\
\hline One application in 2002 & Dec. 2002 & May 2003 & Aug. 2003 (1 d after irrigation) \\
& Dec. 2003 & May 2004 & Aug. 2003 (20 d after irrigation) \\
& Oct. 2004 & May 2005 & Aug. 2005 (30 d after irrigation) \\
Two applications in 2003 and 2004 & Dec. 2003 & May 2004 & Aug. 2003 (1 d after irrigation) \\
& Oct. 2004 & May 2005 & Aug. 2003 (20 d after irrigation) \\
Three applications in 2002, 2003, & Dec. 2003 & May 2004 & Aug. 2005 (30 d after irrigation) \\
$\begin{array}{l}\text { and 2004 } \\
\text { Oct. 2004 }\end{array}$ & May 2005 & Aug. 2003 (20 d after irrigation) \\
\hline
\end{tabular}

$\mathrm{EC}=$ electrical conductivity; $\theta v=$ volumetric moisture content; $\mathrm{Db}=$ bulk density.

( 2.5 to $5.0 \mathrm{~cm}$ in length) and narrow (2.4 to $7.9 \mathrm{~mm}$ in diameter). A more thorough description of wood chips was previously given (Tahboub et al., 2007). Pecan wood chips (C: N ratio of $143: 1)$ were incorporated (disked to $10 \mathrm{~cm}$ ) in May 2002, June 2003, and May 2004 to achieve one application, two applications, or three applications.

Experimental treatments were arranged in a control plus a two-way factorial of four rates of wood chips and two inorganic nitrogen fertilizer treatments (an unfertilized treatment (N0) and a fertilized (N1) treatment to adjust the $\mathrm{C}: \mathrm{N}$ ratio of wood chips to $30: 1$ ) in four blocks. Wood chip application rates were $4484(\mathrm{C} 1), 8968(\mathrm{C} 2), 13,452(\mathrm{C} 3)$, and $17,936(\mathrm{C} 4) \mathrm{kg} \cdot \mathrm{ha}^{-1}$ and corresponded to the amount of pruning wood typically observed on the ground from light to heavy pruning. The inorganic nitrogen (ammonium sulfate) treatment $(\mathrm{N} 1)$ included rates of nitrogen at $15.2,30.5,45.7$, and $61.0 \mathrm{~kg} \cdot \mathrm{ha}^{-1}$ to adjust the $\mathrm{C}: \mathrm{N}$ ratio of wood chips to $30: 1$. The experimental design was a randomized complete block with nine treatments and three application times (one application in 2002; two applications, one in 2003 and one in 2004; or three applications, one in 2002, one in 2003, and one in 2004) and each treatment combination was replicated four times. The first set of plots received treatments in May 2002 only, the second set received treatments in June 2003 and May 2004, and the third set received treatments in May 2002, June 2003, and May 2004. Plots were $2.5 \times 2.5 \mathrm{~m}$ and $2.0 \mathrm{~m}$ apart from each other within each block. A more complete description of the experimental site, design, wood chip amendments, and treatment application were previously described (Tahboub et al., 2007).

Parameters measured included soil reaction $(\mathrm{pH})$, soluble salts as determined by EC, volumetric moisture content $(\theta v)$, bulk density $(\mathrm{Db})$, organic matter (OM), and aggregate stability. Soil samples for $\mathrm{pH}, \mathrm{EC}$, and OM were taken at a depth of 0 to $20 \mathrm{~cm}$. Three soil subsamples were taken from each treatment combination and mixed into one composite sample. Representative samples taken from each composite sample were immediately air-dried for $72 \mathrm{~h}$, ground to pass through a $2.0-\mathrm{mm}$ sieve, and stored at $4{ }^{\circ} \mathrm{C}$ until analysis.

Soil $\mathrm{pH}$ and EC were determined from soil-saturated paste extracts (Rhoades, 1982) and measurements were taken in Dec. 2002,

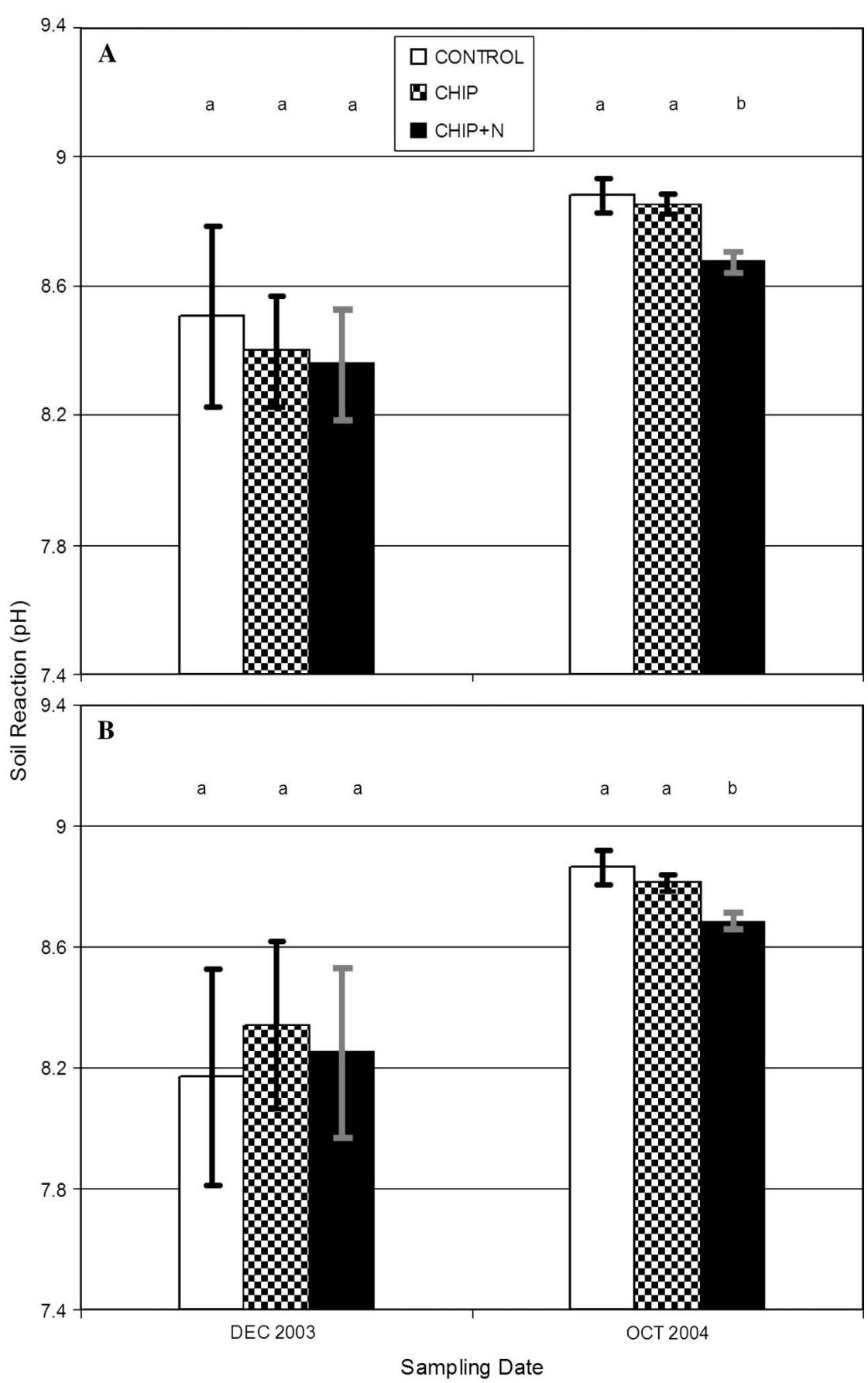

Fig. 1. Soil reaction $(\mathrm{pH})$ as influenced by the nitrogen treatments averaged overall other treatments. Treatments were applied in summer of 2003 and 2004 (A) and summer of 2002, 2003, and 2004 (B). Error bars represent \pm SE. Means within each sampling date with the same letter are not significantly different at $\alpha=0.05$. 
Dec. 2003, and Oct. 2004 for the set of plots that received one wood chip application in May 2002. For the plots that received two and three wood chip applications, soil pH and EC were measured in Dec. 2003 and Oct. 2004 (Table 1). Soil OM analysis was by the Walkley-Black method (Nelson and Sommers, 1982) and measurements were taken in May 2003, 2004, and 2005 for the first set of plots that received one application in May 2002. For the plots that received two and three treatment applications, soil organic matter was measured in May 2003 and 2004 (Table 1).

A surface moisture-density gauge (Troxler Model 3440; Troxler Electronic Laboratories, Research Triangle Park, NC) was used to determine the soil $\mathrm{Db}$ and the $\theta$ ) of all treatment combinations at a depth of 0 to 15 $\mathrm{cm}$. The gauge was calibrated for the $\theta v$ using the technique described by Topp and Ferre (2002). Eighteen random field core samples were taken at a depth of 0 to $15 \mathrm{~cm}$ and at various soil moisture levels to determine the gravimetric moisture content $(\theta \mathrm{g})$ and mean $\mathrm{Db}$ of the soil. The $\theta v$ was determined by multiplying the calculated $\theta \mathrm{g}$ by the mean $\mathrm{Db}$. The $\theta v$ were plotted against preliminary measured moisture count ratios (gauge readings) to obtain the calibration curves as well as the regression equation.

The surface moisture-density gauge uses gamma radiation backscattering to nondestructively sample relatively large volumes of soil to estimate the wet bulk density (Dbw), which is a function of $\mathrm{Db}$ and water content. The gauge was calibrated for the $\mathrm{Db}$ using the technique described by Blake (1965) and involved measurements on large containers containing soils that had been compacted artificially to a desired Dbw. The Dbw were calculated from the mass and volume of wet soils and were plotted against preliminary measured density count ratios (gauge readings) to obtain the calibration curve and the regression equation. The $\mathrm{Db}$ was predicted from the Dbw by the following equation:

$$
\mathrm{Db}=\mathrm{Dbw} /(1+\theta \mathrm{g} / 100) .
$$

Soil $\mathrm{Db}$ and $\theta v$ of all three sets of plots that received one, two, and three treatment applications in May 2002, June 2003, and May 2004 were measured $1 \mathrm{~d}$ and $20 \mathrm{~d}$ after irrigation in Aug. 2003 and $30 \mathrm{~d}$ after irrigation in Aug. 2005 (Table 1).

Soil samples for aggregate stability measurements were taken at a depth of $5 \mathrm{~cm}$ from each experimental plot and were immediately air-dried until measurements were taken. Soil aggregate stability was measured for all experimental plots in May 2005 (Table 1). Aggregate stability was determined using the technique described by Herrick et al. (2001). Nine aggregates of 6 to $8 \mathrm{~mm}$ in diameter from each plot were rated on a scale of 1 to 6 based on a combination of visual observations of slaking during the first $5 \mathrm{~min}$ after immersion in deionized water and the percent remaining on a $1.5-\mathrm{mm}$ sieve after five dipping cycles.

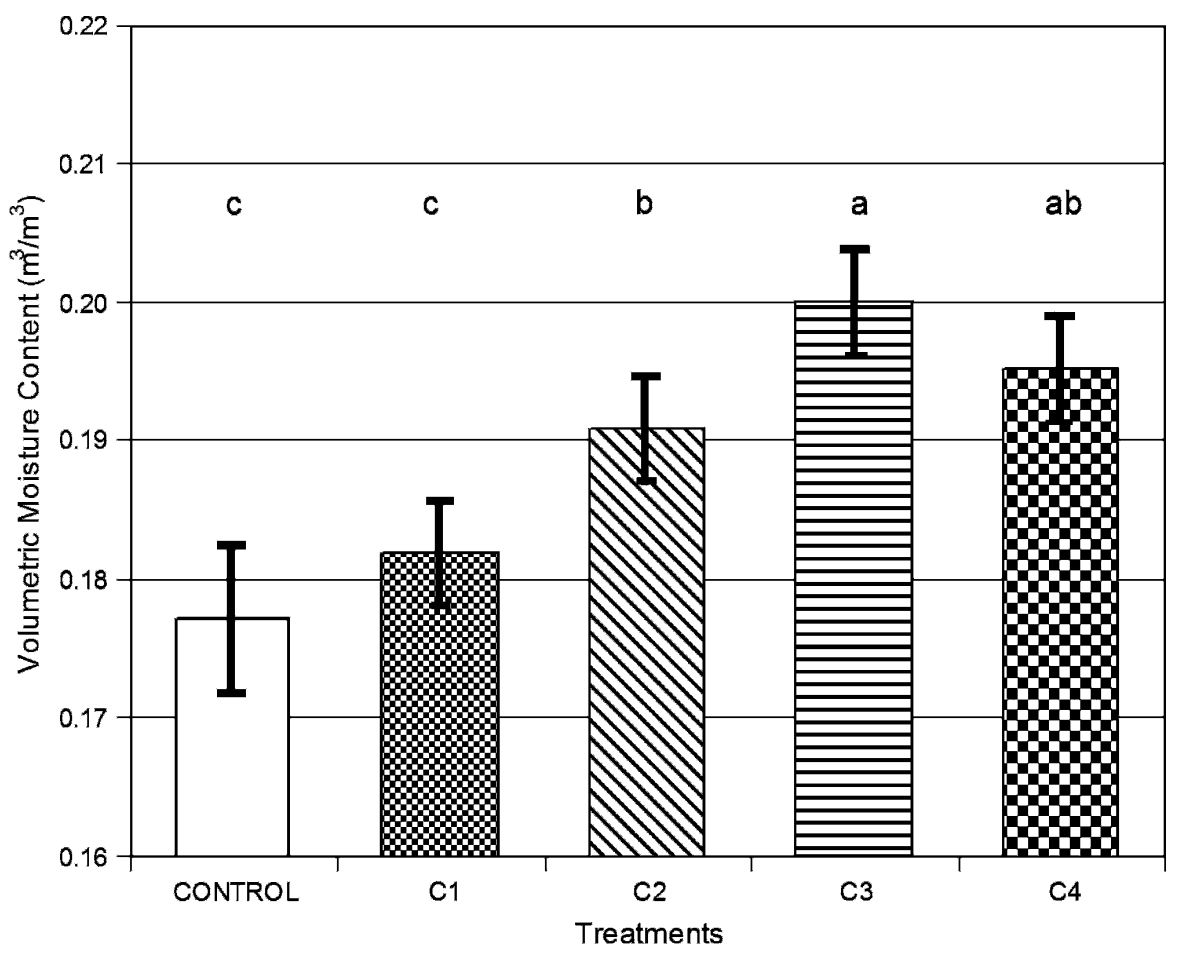

Fig. 2. Soil volumetric moisture content twenty days after irrigation in Aug. 2003 as influenced by the wood chip rates averaged overall other treatments. Treatments with $\mathrm{C} 1, \mathrm{C} 2, \mathrm{C} 3$, and $\mathrm{C} 4$ received chips at $4484,8968,13,452$, and $17,936 \mathrm{~kg} \cdot \mathrm{ha}^{-1}$ in May 2003, respectively. Error bars represent $\pm \mathrm{SE}$. Means with the same letter are not significantly different at $\alpha=0.05$.

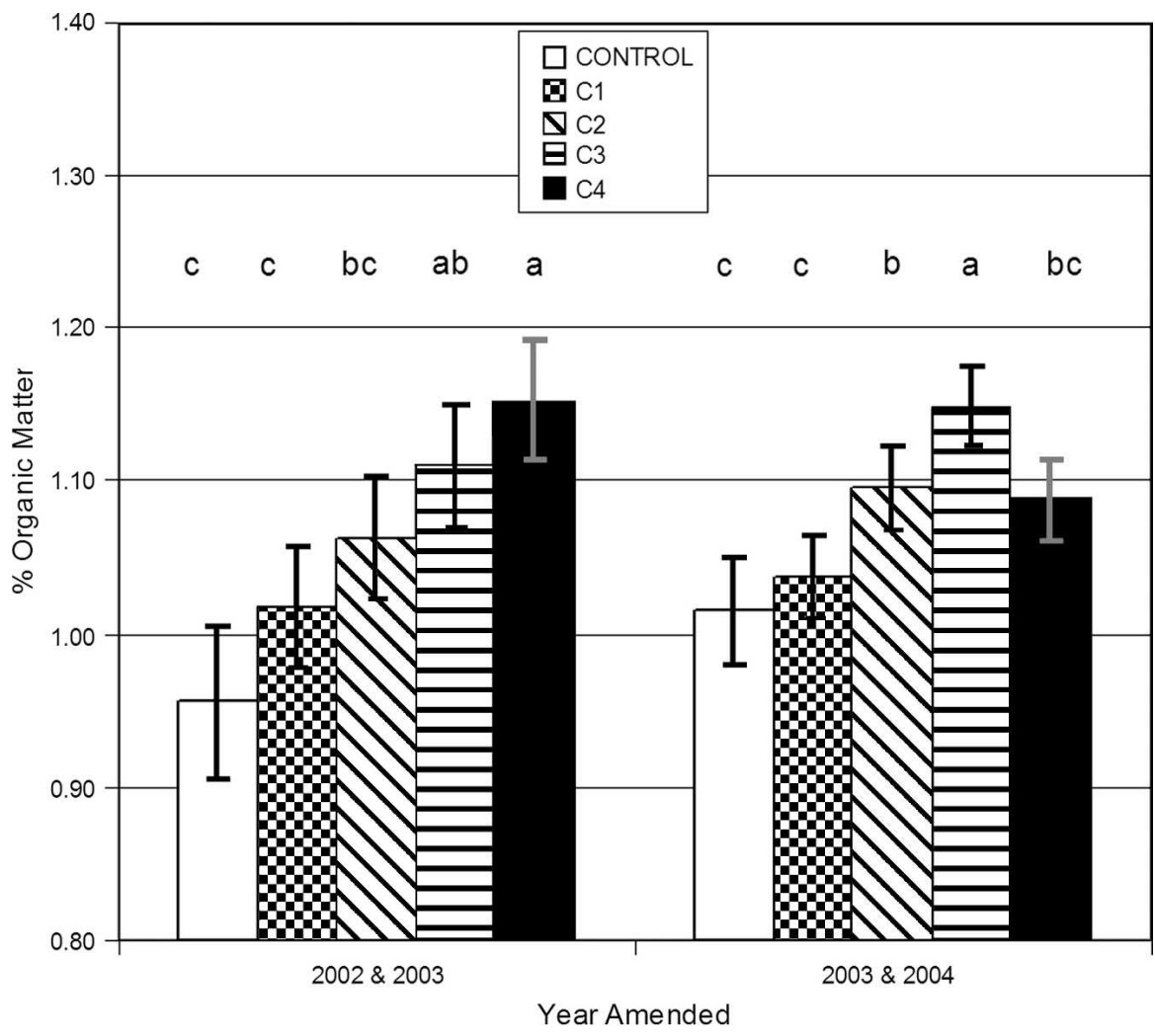

Fig. 3. Soil organic matter content 1 year after two treatment applications as influenced by the wood chip rates averaged overall other treatments. Treatments with C1, C2, C3, and C4 received chips at 4484 , $8968,13,452$, and 17,936 kg.ha ${ }^{-1} \cdot \mathrm{yr}^{-1}$, respectively. Error bars represent $\pm \mathrm{SE}$. Means within each set of amendment years with the same letter are not significantly different at $\alpha=0.05$. 
Soil measurements were analyzed by each set of plots and sampling time separately using analysis of variance by the Mixed procedure of SAS (SAS Institute Inc., 1997). Proc Mixed was used to calculate F statistics for the overall treatment effect and for contrasts for the wood chip main effect, the nitrogen fertilization main effect, and for the wood chip simple effects with no nitrogen. The simple effects of the wood chips with no added nitrogen are comparisons among $\mathrm{C} 1 \mathrm{~N} 0, \mathrm{C} 2 \mathrm{~N} 0, \mathrm{C} 3 \mathrm{~N} 0$, and $\mathrm{C} 4 \mathrm{~N} 0$. In addition, means with SES were calculated for the nine treatments and estimate statements were used to calculate wood chip and nitrogen main effect means and sEs. Least significant differences were used to carry out pairwise comparisons of the nine treatments to determine if they were significant at a significance level of $\alpha=0.05$.

\section{Results and Discussion}

At the end of the growing season, most of the applied wood chips had entirely degraded, and the remaining larger chips were degraded to the point that no brittle wood remained to interfere with mechanical harvest. One year after application, some wood chips were still evident in the soil, particularly at the higher application rates $\left(13,452\right.$ and $\left.17,936 \mathrm{~kg} \cdot \mathrm{ha}^{-1}\right)$, but the remaining chips were degraded to the point of flexible shreds. Wood chips remaining tended to be short lengths of woody twigs that had passed unscathed through the tub grinder.

No statistical differences $(P>0.05)$ for soil $\mathrm{pH}$ among all treatments were observed for the single wood chip application measured in Dec. 2002, Dec. 2003, and Oct. 2004. One treatment application of pecan wood chips did not influence soil $\mathrm{pH}$ for a period of three seasons after treatment application.

For the plots that received two treatment applications in May 2003 and 2004, soil pH was measured after one application in Dec. 2003 and after two treatment applications in Oct. 2004. Similar to the plots that received only one treatment application in May 2002, soil $\mathrm{pH}$ measured after one treatment application in Dec. 2003 was not statistically $(P>$ 0.05 ) different among treatments (Fig. 1A). The addition of ammonium sulfate to balance the $\mathrm{C}: \mathrm{N}$ ratio of pecan chips decreased soil $\mathrm{pH}$ after two treatment applications (Fig. 1A). Soil $\mathrm{pH}$ in the control and chip-amended soil was not statistically different. Furthermore, no tendency was observed $(P>0.05)$ for soil $\mathrm{pH}$ to change with increasing wood chip application rate (data not shown).

A similar tendency of decreasing soil $\mathrm{pH}$ with the addition of nitrogen to adjust the $\mathrm{C}$ : $\mathrm{N}$ ratio of pecan wood chips was observed $[\mathrm{F}(8,24)=3.18, P=0.0132]$ for the plots that received three treatment applications in May 2002, 2003, and 2004 when measured after three seasons in Oct. 2004 (Fig. 1B). The decrease in soil $\mathrm{pH}$ with addition of ammonium sulfate is attributed to the acidifying effect of ammonium sulfate. The addition of

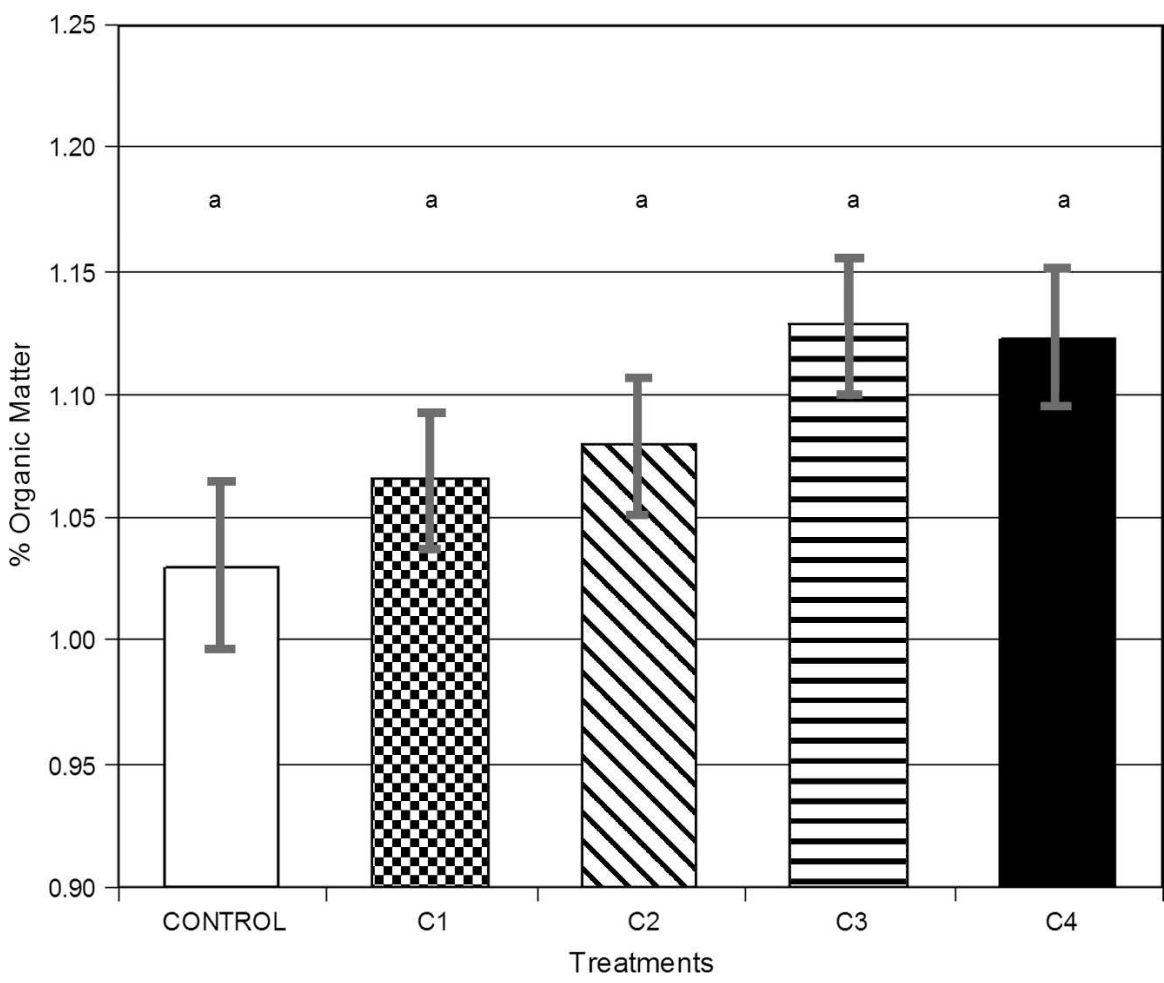

Fig. 4. Soil organic matter content 1 year after three treatment applications as influenced by the wood chip rates averaged overall other treatments. Treatments with C1, C2, C3, and C4 received chips at 4484, $8968,13,452$, and $17,936 \mathrm{~kg} \cdot \mathrm{ha}^{-1} \cdot \mathrm{yr}^{-1}$, respectively. Error bars represent \pm SE. Means with the same letter are not significantly different at $\alpha=0.05$.

ammonium fertilizers (such as ammonium sulfate) has a strong acidifying effect on the soil (Havlin et al., 1999; Krishna, 2002). Ammonium sulfate has three times the acidifying effect on soil $\mathrm{pH}$ compared with ammonium nitrate, urea, or urea ammonium nitrate solution. On the conversion of ammonium to nitrate, the ammonium ion produces 5.35 pounds of acidity per pound of nitrogen applied, which in turn makes ammonium sulfate the most acidifying of these $\mathrm{N}$ sources (Sartain and Kruse, 2001).

Incorporation of pecan chips had no significant effect $(P>0.05)$ on soil EC for the plots that received one, two, or three treatment applications. This lack of response on soil EC was expected and was attributed to the low salt content in pecan wood. The ash content of pecan wood is $0.4 \%$ on an ovendried weight basis (Pettersen, 1984). On the other hand, Patriquin et al. (1993) indicated that soil EC is tightly linked to nitrate nitrogen concentration in the soil. The authors, while studying the effect of various organic amendments on soil $\mathrm{pH}, \mathrm{EC}$, and nitrate, indicated that the growth of plants reduced soil nitrate and EC to a greater extent than the incorporation of immobilizing residues. Furthermore, Werner (1997) observed relatively stable EC levels under organic compared with conventional systems.

Incorporation of pecan chips had little effect on soil $\theta v$. The effect of one wood chip treatment application was only significant in Aug. 2003 for the plots that received treatment in May 2003 and 2004. Pecan chips applied in 2003 statistically $[F(8,24)=2.87$,
$P=0.0217]$ increased soil $\theta v$ at the three highest wood chip rates (Fig. 2). The positive effect of one treatment application on soil $\theta v$ in Aug. 2003 was also noticed on the soil $\theta \mathrm{g}$ for the same plots (data not shown). However, pecan wood chips applied in 2003 increased soil $\theta \mathrm{g}$ only at the highest wood chip rate. The incorporation of pecan wood chips had no significant effect $(P>0.05)$ on soil $\theta v$ for the plots that received two or three treatment applications.

The lack of influence of pecan wood chip incorporation on soil $\theta v$ was attributed to the fine texture of the soil ( $\approx 46 \%$ clay). The results of this study agree with the results obtained by Bauer and Black (1992) who indicated that the effect of organic amendments on soil water availability is generally positive, but whether the effect is significant depends on other soil parameters such as texture. The authors found that the effect of soil organic matter on soil water availability tends to be more pronounced in coarsetextured than fine-textured soils.

In this study, the application of pecan wood chips had little effect on soil $\theta v$. However, the silty clay soil at the research site has a high waterholding capacity and pecan wood chip incorporation was not expected to greatly increase water retention. Pecan chip amendment would be more likely to increase the waterholding capacity of coarser textured soils.

Incorporation of pecan chips had no significant effect $(P>0.05)$ on soil Db regardless of application rates or number of applications. Numerous studies have addressed 
the beneficial effect of organic amendments on decreasing soil bulk density (Nemati et al., 2000; Webber, 1978; Weil and Kroontje, 1979). The insignificant effect of pecan wood chip incorporation on soil $\mathrm{Db}$ was attributed to the lack of readily decomposable organic constituents of pecan wood. Nemati et al. (2000) indicated that the lack of response on $\mathrm{Db}$ from a compost treatment compared with the deinking and secondary sludge amendments was probably the result of the lack of readily decomposable organic constituents that were entirely consumed during the composting process. The beneficial effects of deinking sludge and secondary sludge amendments might have resulted from the rapid increase in aggregate stability. Paper sludge amendments as a source of carbon for microorganisms can also stimulate the production of binding agents (polysaccharides, illhumidified organic materials, or lipids) that rapidly aggregate soil particles.

Soil organic matter content 1,2 , or 3 years after one treatment application was not significantly $(P>0.05)$ different in the experimental plots that received one treatment application in May 2002. The incorporation of pecan wood chips increased soil organic matter content 1 year after two treatment applications at the two highest wood chip rates $[\mathrm{F}(8,24)=2.97, P=0.0185]$ in May 2004 and at the second and third highest rates $[\mathrm{F}(8,24)=2.97, P=0.0184]$ in May 2005 (Fig. 3). Although a similar trend of increasing soil organic matter content occurred with increasing pecan wood chip rates, soil organic matter 1 year after three treatment applications was not statistically different $(P=0.06)$ among all treatments (Fig. 4).

Soil organic matter content increased as pecan wood chips input increased. The increase in soil organic matter was attributed to the high content of recalcitrant constituents such as lignin in pecan wood that contribute much more to soil organic matter (humus) than organic materials composed of hydrophilic constituents such as protein and plant tissue polysaccharides. Schnitzer (1978) indicated that organic residues rich in recalcitrant constituents such as lignin and other polyphenols decompose more slowly and contribute much more significantly to soil organic matter (humus) than proteins and sugars. Furthermore, Lal (2003) indicated that the use of high-lignin recalcitrant amendments increased soil organic carbon.

Soil aggregate stability 3 years after one treatment application was not significantly $(P>0.05)$ different in the experimental plots that received treatments in May 2002. Soil aggregate stability 1 year after two and three treatment applications was statistically higher at the two and three highest wood chip rates averaged overall other treatments, respectively (Fig. 5A-B). Although the increase in soil aggregate stability with increasing pecan wood chip inputs was significant, the increase in soil aggregate stability was slow and the aggregate stability values did not exceed 2.75 on the 1 to 6 aggregate stability scale. The increase in aggregate stability was attributed

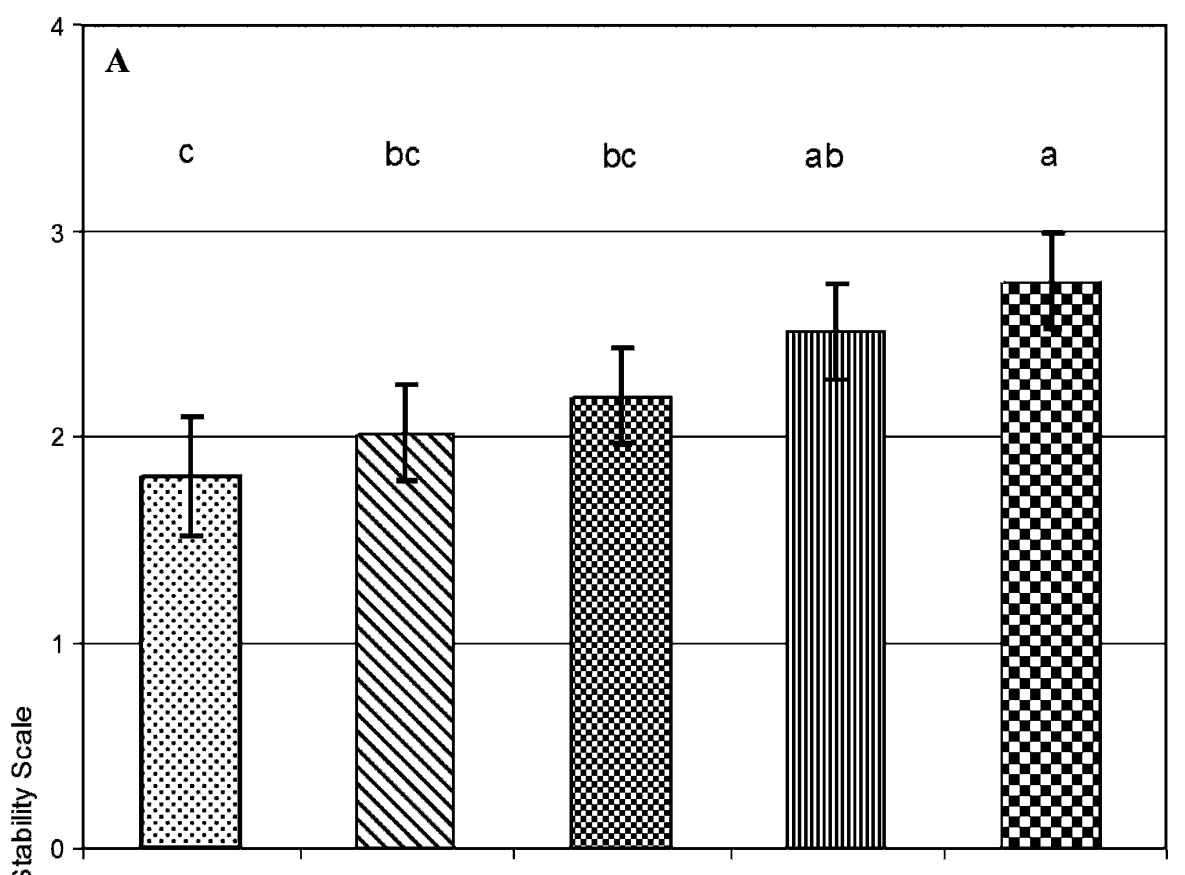

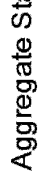

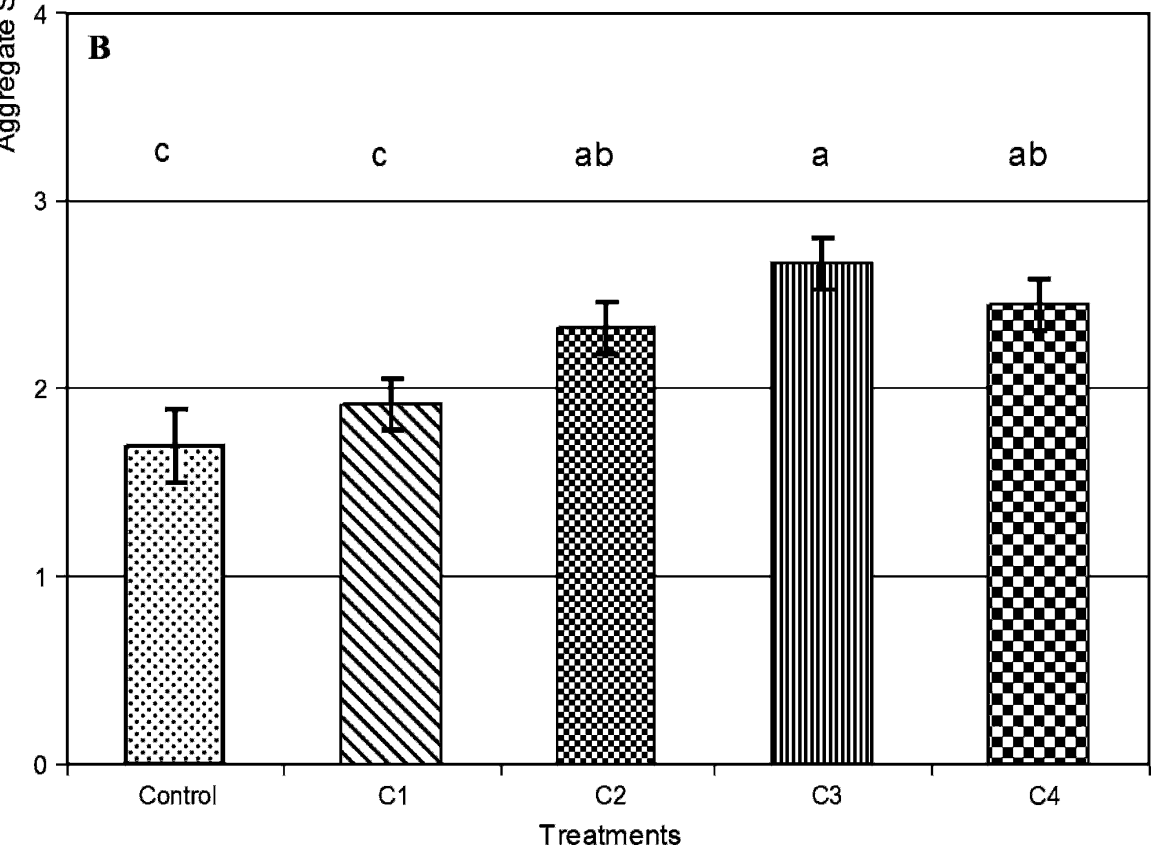

Fig. 5. Soil aggregate stability 1 year (May 2005) after two treatment applications (A) and three treatment applications (B) as influenced by the wood chip rates averaged overall other treatments. Treatments with $\mathrm{C} 1, \mathrm{C} 2, \mathrm{C} 3$, and C4 received chips at 4484, 8968, 13,452, and 17,936 $\mathrm{kg} \cdot \mathrm{ha}^{-1} \cdot \mathrm{yr}^{-1}$, respectively. Error bars represent \pm SE. Means within each set of treatment applications with the same letter are not significantly different at $\alpha=0.05$.

to the high content of hydrophobic constituents such as lignin in pecan wood that are likely to be more effective and longer-lasting aggregate-binding agents than organic materials composed of hydrophilic constituents such as root exudates and plant tissue polysaccharides.

The results of this study agree with the results obtained by Martens (2000) who found that aggregate stability increased in organic residue-amended soil, and the process was related to the biochemical composition of the plant residues. Residues with high carbohydrate and amino acid contents decomposed quickly and resulted in quick but short-term aggregate stability, but longerterm aggregation was noted from residues with slower decomposition rates and higher concentrations of phenolic acids. Furthermore, Tisdall and Oades (1982) found organic residues with slower decomposition rates such as wood resulted in persistent soil aggregation accompanied by an increase in soil organic carbon. Kong et al. (2005) found that aggregate stability increased linearly with both carbon inputs $\left(\mathrm{r}^{2}=0.75\right)$ and soil organic carbon $\left(\mathrm{r}^{2}=0.63\right)$. Piccolo and Mbagwu (1999) found that as organic carbon 
inputs increased aggregate stability increased. The authors indicated that soil amendments with exogenous humidified or hydrophobic organic constituents appear to be most suitable for improving soil physical quality. The positive effect of hydrophobic materials on aggregate stability has been also observed by Capriel et al. (1990), who found a high correlation coefficient $\left(\mathrm{r}^{2}=0.91\right)$ between aggregate stability and the aliphatic (hydrophobic) fraction of organic residues.

The chipping and incorporation of wood chips is an alternative to the burning of waste wood if environmental constraints do not allow burning. Chipping and incorporation is expensive. Depending on the size and quantity of wood and the type of self-propelled chipper, the estimated cost for chipping and incorporation in New Mexico is $\$ 296$ to $493 /$ ha (\$120 to $200 /$ acre) whereas dragging the pruned wood to the end of the field costs $\$ 74$ to $123 /$ ha ( $\$ 30$ to $50 /$ acre).

\section{Conclusions}

Wood chip amendments had no effect on soil $\mathrm{pH}, \mathrm{EC}$, or bulk density after one, two, or three treatment applications. Incorporation of pecan wood chips only significantly affected soil volumetric moisture content on one sampling date. Pecan chip amendment would likely increase the waterholding capacity of coarse-textured soils that have lower waterholding capacities than the silty clay soil used in the current study. Pecan wood chip incorporation enhanced soil organic matter and aggregate stability at the higher application rates. The incorporation of chipped pecan pruning wood into the soil appears to improve soil tilth while providing growers with an environmentally benign means of disposal.

\section{Literature Cited}

Bauer, A. and A.L. Black. 1992. Organic carbon effects on available water capacity of three soil textural groups. Soil Sci. Soc. Amer. J. 56:248254.

Blake, G.R. 1965. Bulk density, p. 374-390. In: Black, C.A., D.D. Evans, J.L. White, L.E. Ensminger, and F.E. Clark (eds.). Methods of soil analysis: Part I: Physical and mineralogical properties. Including statistics of measurement and sampling. ASA, Madison, WI.

Boggs, L.C., A.C. Kennedy, and J.P. Reganold. 2000. Organic and biodynamic management: Effects on soil biology. Soil Sci. Soc. Amer. J. 64:1651-1659.

Cabral, D. 2005. A feasibility study for alternatives for the commercial utilization of pecan wood waste from pruning New Mexico orchards. The New Mexico Manufacturing Extension Partnership, Albuquerque, NM.

Capriel, P., T. Beck, H. Borchert, and P. Härter. 1990. Relationship between soil aliphatic fraction extracted with supercritical hexane, soil microbial biomass, and soil aggregate stability. Soil Sci. Soc. Amer. J. 54:415-420.

Drinkwater, L.E., D.K. Letourneau, F. Workneh, A.H.C. Van Bruggen, and C. Shennan. 1995. Fundamental differences between conventional and organic tomato agroecosystems in California. Ecol. Appl. 5:1098-1112.

Free, G.R. 1971. Soil management for vegetable production on honeoye soil with special reference to the use of hardwood chips. New York Food and Life Sciences Bull. 2. Cornell University Agricultural Experiment Station, New York State College of Agriculture and Life Sciences, Cornell University, Ithaca, NY.

Havlin, J.L., J.D. Beaton, S.L. Tisdale, and W.L. Nelson. 1999. Soil fertility and fertilizers: An introduction to nutrient management. Prentice Hall, Inc., Upper Saddle River, NJ.

Herrick, J.E., W.G. Whitford, A.G. de Soyza, J.W. Van Zee, K.M. Havstad, C.A. Seybold, and M. Walton. 2001. Field soil aggregate stability kit for quality and rangeland health evaluations. CATENA 44:27-35.

Holtz, B.A. 1999. Wood chipping to reduce air pollution and build soil organic matter, p. 100 101. In: 27th Annual Almond Industry Conf. Proc., 1-2 Dec. 1999. Almond Board of California, Modesto, CA.

Holtz, B.A., M.V. McKenry, and T.C. CaesarTonThat. 2004. Wood chipping almond brush and its effect on the almond rhizosphere, soil aggregation and soil nutrients. Acta Hort. 638:127-137.

Kong, A.Y.Y., J. Six, D.C. Bryant, R.F. Denison, and C.V. Kessel. 2005. The relationship between carbon input, aggregation, and soil organic carbon stabilization in sustainable cropping systems. Soil Sci. Soc. Amer. J. 69:1078-1085.

Krishna, K.R. 2002. Soil fertility and crop production. Science Publishers, Inc., Enfield, NH.

Lal, R. 2003. Carbon sequestration in dryland ecosystems. Environ. Manage. 33:528-544.

Magdoff, F. 1992. Building soils for better crops: Organic matter management. Univ. Nebraska Press, Lincoln, NB.

Martens, D.A. 2000. Plant residue biochemistry regulates soil carbon cycling and carbon sequestration. Soil Biol. Biochem. 32:361369.

Nelson, D.W. and L.E. Sommers. 1982. Total carbon, organic carbon, and organic matter, $\mathrm{p}$. 539-579. In: Page, A.L., R.H. Miller, and D.R. Keeney (eds.). Methods of soil analysis: Part 2: Chemical and microbiological properties. Monograph Number 9. 2nd ed. ASA, Madison, WI.

Nemati, M.R., J. Caron, and J. Gallichand. 2000. Using paper de-inking sludge to maintain soil structural form: Field measurements. Soil Sci. Soc. Amer. J. 64:275-285.

New Mexico Air Quality Bureau. 2003. Smoke management. Title 20, Chapter 2, Part 65. 31 Dec. 2003. <http://www.nmenv.state.nm.us/ aqb/regs/20_2_65nmac_123103.pdf $>$.

Oades, J.M. 1984. Soil organic matter and structural stability: Mechanisms and implication for management. Plant Soil 76:319-337.
Patriquin, D.G., H. Blaikie, M.J. Patriquin, and C. Yang. 1993. On-farm measurements of $\mathrm{pH}$, electrical conductivity and nitrate in soil extracts for monitoring coupling and decoupling of nutrient cycles. Biol. Agr. Hort. 9:231272.

Pettersen, R.C. 1984. The chemical composition of wood, p. 57-126. In: Rowell, R. (ed.). The chemistry of solid wood. Amer. Chem. Soc., Washington, DC.

Piccolo, A. and J.S.C. Mbagwu. 1999. Role of hydrophobic components of soil organic matter in soil aggregate stability. Soil Sci. Soc. Amer. J. 63:1801-1810.

Reganold, J.P. 1993. Effects of alternative and conventional farming systems on agricultural sustainability, p. 1-5. In: Bay-etersen, J. (ed.). Sustainable agriculture for the Asian and Pacific region. Food \& Fertilizer Technology Center, Taipei, Taiwan.

Rhoades, J.D. 1982. Soluble salts, p. 167-179. In: Page, A.L., R.H. Miller, and D.R. Keeney (eds.). Methods of soil analysis: Part 2: Chemical and microbiological properties. Monograph Number 9. 2nd ed. ASA, Madison, WI.

Sanborn, P., C. Bulmer, and D. Coopersmith. 2004. Use of wood waste in rehabilitation of landings constructed on fine-textured soils, central interior British Columbia, Canada. Western J. Appl. Forestery. 19:175-183.

Sartain, J.B. and J.K. Kruse. 2001. Selected fertilizers used in turfgrass fertilization. Florida Coop. Ext. Ser. Institute of Food and Agricultural Sciences CIR1262. Univ. of Florida, Gainesville, FL.

SAS Institute Inc. 1997. SAS/STAT ${ }^{\circledR}$ software: Changes and enhancements through Release 6.12. SAS Institute, Cary, NC.

Schnitzer, M. 1978. Humic substances: Chemistry and reactions, p. 1-64. In: Schnitzer, M. and S.U. Khan (eds.). Soil organic matter. Elsevier Scientific Publishing Company, New York, NY.

Tahboub, B.M., W.C. Lindemann, and L. Murray. 2007. Nutrient availability in soil amended with pecan wood chips. HortScience. 42:339343.

Tisdall, J.M. and J.M. Oades. 1982. Organic matter and water-stable aggregates in soils. J. Soil Sci. 33:141-163.

Topp, G.C. and P.A. Ferre. 2002. The soil solution phase, p. 417-1071. In: Dane, J.H. and G.C. Topp (eds.). Methods of soil analysis. Part 4: Physical methods. SSSA Inc., Madison, WI.

Wallace, A., G.A. Wallace, and J.W. Cha. 1990. Soil organic matter and the global carbon cycle. J. Plant Nutr. 13:459-466.

Webber, L.R. 1978. Incorporation of nonsegregated, noncomposted solid waste and soil physical properties. J. Environ. Qual. 7:397400.

Weil, R.R. and W. Kroontje. 1979. Physical condition of a Davidson clay loam after five years of heavy poultry manure applications. J. Environ. Qual. 8:387-392.

Werner, M.R. 1997. Soil quality characteristics during conversion to organic orchard management. Appl. Soil Ecol. 5:151-167. 